[Transaction ]

Journal of the Korean Society of Clothing and Textiles

Vol. 33, No. 6 (2009) p.869 879

\title{
A Study on Tecktonik Culture and Fashion
}

\author{
Sanghee Kwon $\cdot$ Jisoo $\mathrm{Ha}^{\dagger}$ \\ Dept. of Clothing \& Textiles, Seoul National University \\ Received March 10, 2009; Revised (May 4, 2009; May 22, 2009); Accepted May 29, 2009 \\ 테크토닉 문화와 패션에 대한 연구 \\ 권상희 · 하지수 \\ 서울대학교 의류학과 \\ 접수일(2009년 3월 10일), 수정일(1차 : 2009년 5월 4일, 완료일 : 2009년 5월 22일), 게재확정일(2009년 5월 29일)
}

\begin{abstract}
The purpose of this study is to understand the Tecktonik culture and fashion, and to compare its features in Korea and France. Unlike prior studies which mainly dealt with subcultures in the U. S. and the U. K., this study paid attention to the condition of Korea. Tecktonik is a dance and music craze that originated in France in 2000, and spread worldwide via the Internet. The main features of Tecktonik fashion are slim fit, vivid colors, and high-top sneakers, which represent current fashion and culture trends, and express the feeling of Tecktonik music and dance. Compared to France, Korean Tecktonik fashion emphasizes sexual attraction of women with short skirt, while men are conservative about mohican hairstyle and dark make-up. In France, Tecktonik has become a sound social amusement, while in Korea it has been used for advertisements or entertainer's fashion style. The subcultural characteristics of Tecktonik were identified as playfulness, the active use of digital media, and high commercial value. In France where Tecktonik is for participating in a joyful dance, playfulness is prominent, and in Korea where Tecktonik acts as a visual entertainment, commercial value is outstanding. It has made differences in Tecktonik fashion of the two countries.
\end{abstract}

Key words: Tecktonik, Tecktonik fashion, Subculture; 테크토닉, 테크토닉 패션, 하위문화

\section{Introduction}

Music and fashion have always been inseparable ever since the emergence of pop music. Since fashion performs an important role in characterizing the music genre, it can be considered as 'visual music'. Music and fashion has affected each other, creating unique subcultural styles such as rockabilly style in

\footnotetext{
Corresponding author

E-mail: jisooha@snu.ac.kr

This study was partially supported by the Research Fund from the Research Institute of Human Ecology of Seoul National University.
}

the 1950s, rockers look in the 1960s, glam look in the 1970s, reggae style and punk look in the 1980s, grunge look, hip-hop style and techno style in the 1990s. Whenever a new music genre appears, a new youth culture emerges forming its unique fashion style (Kim et al., 2006).

In fashion and clothing science area, there have been many studies on the subcultural style related to music. For instance, Kim and Lee (2003) examined pop stars' fashion style from the 1950s to the 1990s, and analyzed rock style, new wave style and reggae hip-hop style in the high fashion. Sohn and Park (2005) and Kim (2002) researched subcultural punk 
style, and identified its influence on the high fashion. In addition, Chung and Guem (2005) analyzed grungy style in the street fashion, high fashion, and musician's fashion, and Kim et al. (2001) examined hip-hop fashion based on its culture. However, most prior studies mainly focused on the subcultures in the United States and the United Kingdom, and not much attention was given to the Korean youth. Also, there has not been enough study on the new subculture after hip-hop style. Only Park and Ha (2008) added emo fashion, a very recent music-related fashion to the list. Therefore, it is necessary to notice the recently emerged subcultural style, and to observe its dissemination in Korea. This study focuses on the Tecktonik culture and fashion that originated in France, in 2000. Since Tecktonik reached Korea directly from France via the Internet unlike prior subcultures, it can be a good case through which we can examine how Koreans enjoy and accept a subculture from a foreign country.

The purpose of this study is to understand the characteristics of Tecktonik culture and fashion style, and to compare its features in Korea and France. For which, following issues were focused on. First, the concept and the origin of Tecktonik was defined. Second, the way people enjoy Tecktonik and its fashion style in France and Korea were examined. And third, the subcultural features of Tecktonik in France and Korea were compared.

Since Tecktonik is a new genre emerged in 2000, there has not been an existing study on Tecktonik yet. Therefore, newspaper articles having interviews with the initiator and fans of Tecktonik were used to find its origin and features. Also, online videos made by Tecktonik fans and companies were analyzed because online video is important element of Tecktonik culture. And information on the subculture and its style was obtained from the books and papers about subculture, pop music and mass culture.

\section{Definition and Origin of Tecktonik}

Tecktonik, also kwon as 'Tck', is a new dance and music genre. According to Wikipedia (2008), the term came from the words 'techno' and 'electronic'. Tecktonik dance is mainly distinguished by hand and arm motions. The dance moves include winding the arms around the head as if brushing and putting gel through hair, pricking the hands here and there like disco, and twining the arms together. In 2000, Tecktonik started from a party 'Tecktonik Killer' which was held at a nightclub in Paris, called Metropolis. The art directors of the club, Alexandre Barouzdin and Cyril Blanc, were bored by techno music, and held a new style party in which electronic music and conventional genres such as jump, techno, trance, and hard style were combined. The party was successful attracting 8,000 attendants ("Mixed dance", 2008). Afterwards, Tecktonik was showcased in the 2007 Paris Techno Parade which is the annual dance music street festival, and received favorable responses from the public ("Tecktonik dance craze", 2007).

Barouzdin and Blanc registered the copyright in 2002 to prevent the party name from being used by others. As a result, the dance became the first registered trademark in France, and eventually 'Tck' became the name of the company. The company made a contract with music publisher EMI to produce Tecktonik music CD. It has also launched a Tecktonik clothing label and a Tecktonik beverage. Furthermore, it runs a dance academy that employs official Tecktonik dancers, and a beauty salon that professionally does a special haircut for Tecktonik ("Turf war", 2008).

Tecktonik spread its explosive popularity to the whole world including the United States ("France's Tecktonik", 2008). This worldwide popularity resulted from the Internet. Tecktonik fans, also known as 'Tecktoners', videotaped their own dance steps, and posted the videos on the Web sites such as YouTube and Dailymotion. A famous Tecktonik dancer, Jey Jey's video on YouTube was downloaded more than seven million times ("Dance of Mabbaki", 2008). Until July 2008, around 33,800 Tecktonik videos were posted on YouTube, and the Tecktonik music album produced by EMI in 2007 was sold as many as 400,000 ("Tecktonik dance craze", 2008). In the videos, Tecktoners were dancing in unexpected places such as street, garage, classroom etc. These exciting and funny videos made young people dance anywhere, not only in a dark club ("Mixed dance", 2008). <Fig. 1> and $<$ Fig. 2> show French youngsters who freely enjoy 


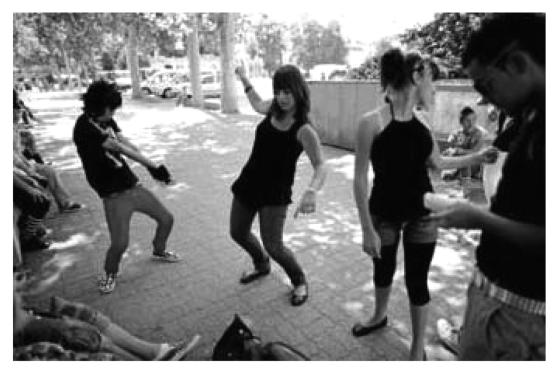

Fig. 1. French teenagers performing a Tecktonik dance on the street.

Retrieved from http://afp.google.com

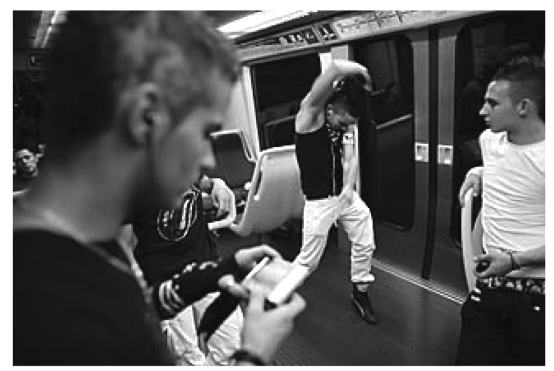

Fig. 2. French youngsters enjoying a Tecktonik dance in a subway.

Retrieved from www.csmonitor.com

Tecktonik in public spaces.

\section{Tecktonik Culture and Fashion in France and Korea}

Although Tecktonik was created in France, Koreans could see how French youngsters enjoyed Tecktonik directly through the online videos. This is a unique phenomenon since most subcultures, such as punk and hippy, began in the western countries but were not transmitted to Korea successfully. Therefore, Tecktonik is a good case to compare the subculture in its birthplace and Korea.

\section{Tecktonik Culture in France}

In France, Tecktonik has become not a simple dance craze but a sound social amusement. Even seven-year-old girl learns a Tecktonik dance at a fitness club (Fig. 3). In an interview done by the Christian Science Monitor ("Parisian twist", 2008), the man-

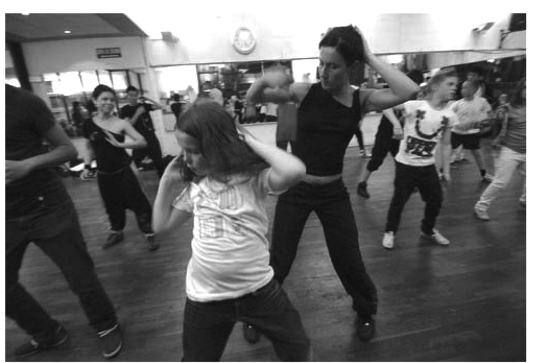

Fig. 3. Students learning a Tecktonik dance at a Paris fitness club.

Retrieved from www.latimes.com

ager of Tecktonik dance team Scorpio expressed the freedom and joy of Tecktonik. He said that Tecktonik is a dance for everyone, unlike hip-hop which is for tall and tough guys. He replied that people perform the dance mainly for enjoyment and fun. His remarks reveal that Tecktonik is open culture for the joy of everyone. Also, another Tecktoner who has danced Tecktonik every Saturday for two years in the nightclub Metropolis explained the positive power of Tecktonik. According to him, Tecktonik helps people relieve the stress so that people do not need to rely on drugs or alcohol. In France, young people used to take drugs to enjoy music in the club. However, to cut the link between drugs and music, Tck Company released a beverage called Energy Drink, and youngsters began to drink it when enjoying Tecktonik ("Mixed dance", 2008). According to another interview done by Agence France Presse ("Tecktonik dance craze", 2007), a 15-year-old French teenager replied that he was a troublemaker who frequently went to the police station for committing crimes, but since starting to enjoy Tecktonik, he stopped doing bad things. For these reasons, parents began to support Tecktonik and believe that it is better for their children to enjoy a new fashion and dance than to hang out on the streets, commit crimes and take drugs ("Mixed dance", 2008).

In short, Tecktonik has been accepted progressively by the French youth without any exclusion or resistance. And it has become considered as a positive social amusement even by the old generation. In France, there is no distinction between performers and audiences because Tecktonik is for participation 
of everyone.

\section{Tecktonik Culture in Korea}

Netizens and clubbers in Korea started to show interests in Tecktonik since the second half of 2007. In February 2008, the first Tecktonik party was held in a club, and a singer, DJ Koo officially showcased Tecktonik music and dance in summer 2008. On Korean online UCC (User Created Contents) sites appeared videos such as 'Tecktonik dance lesson' and 'Tecktonik of DJ Koo' ("Future clothes", 2008). Unlike in France, however, Tecktonik fashion gained more attention than dance or music, while the dance was used for marketing or promoting strategy of companies.

The famous young music groups such as Bigbang or SHINee played an important role in making Tecktonik fashion popular in Korea ("Future clothes", 2008). Although they did not pursue Tecktonik music, their fresh fashion drew attention from youngsters, by wearing Tecktonik fashion items even before Tecktonik was known to the general public in Korea. For example, Bigbang added Tecktonik style to hip-

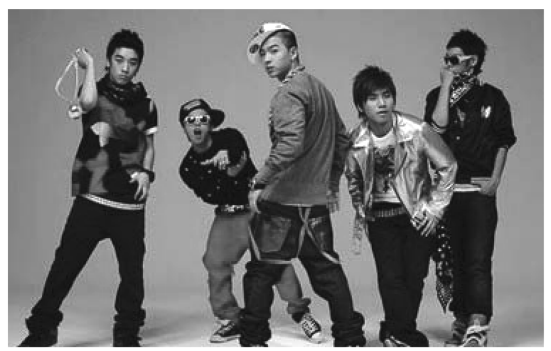

Fig. 4. Fashion of Bigbang produced by combining Tecktonik and hip-hop style.

Retrieved from http://blog.naver.com

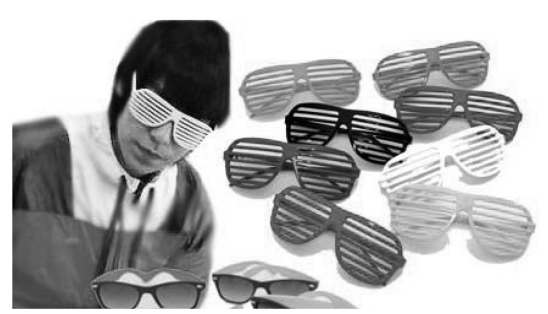

Fig. 5. A member of Bigbang wearing shutter shade sunglasses.

Retrieved from www.kukinews.com hop fashion by wearing neon color items, high-top sneakers and shutter shade sunglasses (Fig. 4) -(Fig. 5). And SHINee wore bright colored skinny pants and high-top sneakers which are main items of Tecktonik fashion (Fig. 6).

The popularity of Tecktonik fashion was revealed in sales volume. On June 2008, a Korean online shopping site Auction announced that Tecktonik fashion items ranked high among the ' 10 hot products in the first half of the year'. Among those products, the boxy T-shirts (that sold 170,000 pieces) and vivid colored skinny jeans (that sold 112,000 pairs) ranked the first and the second respectively. High-top shoes (that sold 57,000 pairs) ranked the sixth. The boxy Tshirts were popular for its vivid neon colors and unique illustrations (“Auction hot products", 2008). The skinny jeans and high-top shoes also gained popularity for vivid colors ("10 hot products", 2008). However, it was not until summer 2008 that the word 'Tecktonik' was used often by Korean media and was recognized by the public. Therefore, it is certain that consumers simply purchased Tecktonik fashion items as a mimicry of popular stars without knowing the relation between the fashion and Tecktonik.

Tecktonik dance and music began to be recognized by the public because of marketing and promotion strategies. For instance, Reebok Korea sponsored Tecktonik parties in famous clubs. In these parties, dancers and entertainers wore colorful high-top shoes of Reebok. Reebok personnel explained that upon using Tecktonik in their promotion strategy, the sales of high-top shoes in acid neon colors continued to grow, and showed more than $30 \%$ of a market share. Also, Etude House, a Korean cosmetics brand, pro-

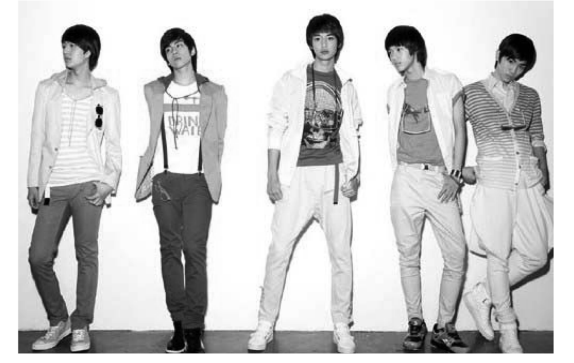

Fig. 6. SHINnee wearing bright colored skinny pants. Retrieved from www.heraldbiz.com 
duced the couple Tecktonik video, and posted it on online sites as a teaser advertisement. In the video, two young famous actor and actress practice a Tecktonik dance, and record the scene as if Tecktoners make their own videos (Fig. 7). Many people found the video so interesting that it was downloaded more than 500,000 times ("Company is engrossed", 2008). An advertisement for OB beer showed university students performing a Tecktonik dance in the classroom (Fig. 8). OB beer also afforded a Tecktonik dance lesson video on its homepage. In addition, a fast food franchise Lotteria used Tecktonik dance to remind consumers its new menu 'Shake, Shake, Chicken' ("Topic in the capital", 2008). In the advertisement, a model performs a Tecktonik dance, grabbing a chicken in his hand. In December 2008, actress Yun-a Song showed Tecktonik dance at Korea Film Awards to celebrate the occasion as a MC of the Awards, and this event drew much attention from the audience. This was also a promotion strategy of the broadcasting station to raise program ratings.

Put it simply, Tecktonik did not settle as a subculture in Korea. Instead, its image was borrowed by main authorities such as the star system, big compa-

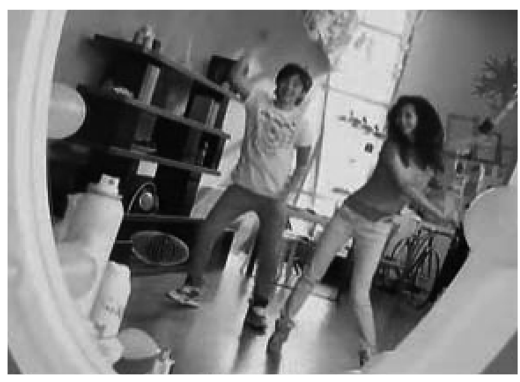

Fig. 7. Advertisement of Etude House.

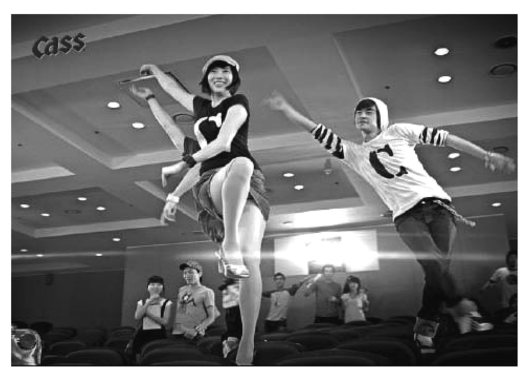

Fig. 8. Advertisement of $O B$ beer. nies and broadcasting stations, only to be commercialized for profits. As a result, Tecktonik has become a visual entertainment in Korea.

\section{Tecktonik Fashion Styles in France and Korea}

This section examines the French and Korean Tecktonik fashion based on online videos, advertisements, and photos in newspaper articles and Internet materials. French Tecktonik fashion was analyzed by using videos and photos of professional dancers and amateur Tecktoners. Korean Tecktonik is led by a small number of singers and advertisements. Thus, Korean Tecktonik fashion was examined based on the fashion styles of singers and models in advertisements.

Tecktonik fashion originated from the clothes worn by French Tecktonik dancers. Its main features are slim fit, vivid colors and high-top sneakers. Tecktoners wear tops in neon colors, tight jumpers or shirts emblazoned with an eagle, and usually wear skinny pants (Fig. 1), (Fig. 10)-(Fig. 11). Eagle is the logo of Tck Company, symbolizing freedom (Fig. 9). Some females put on short pants <Fig. 12> or short

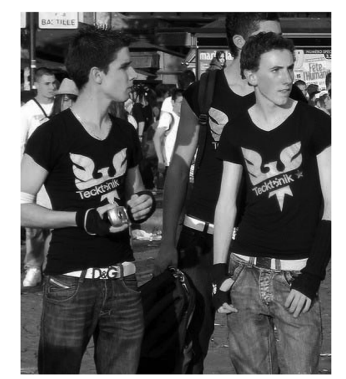

Fig. 9. French Tecktoners.

Retrieved from www.flickr.com

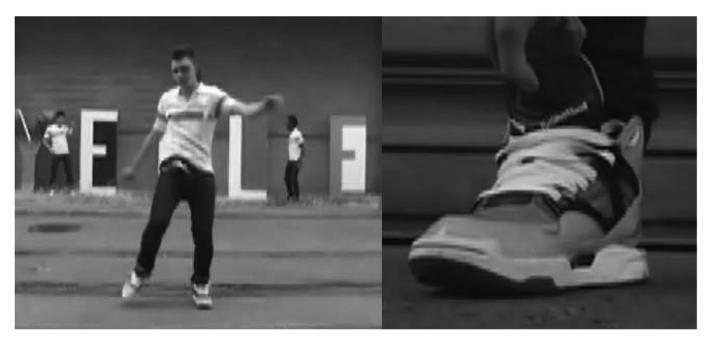

Fig. 10. A Tecktoner and his high-top sneakers. From Yelle. (2007). Music video "A cause des garcons". 
skirts. Male Tecktoners have mohican haircut, the shaven hairstyle with only the middle part left (Fig. 13)-(Fig. 14). Tecktoners put on smoky eye make-up, or draw a star pattern around one eye (Fig. 13). Also, they tattoo on their upper bodies or arms with neon

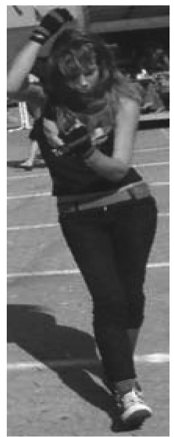

Fig. 11. A female Tecktoner in skinny pants and a neon colored belt.

Retrieved from www.zakshow. com

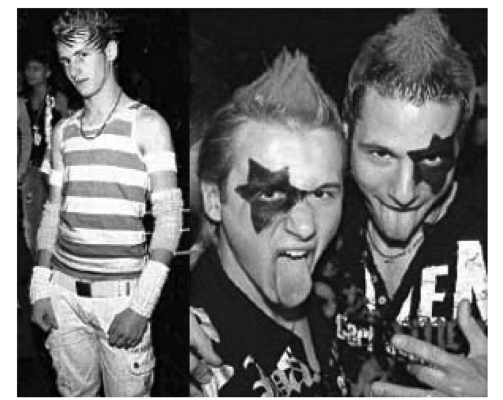

Fig. 13. Armbands and mohican haircuts. Retrieved from www.joins.com

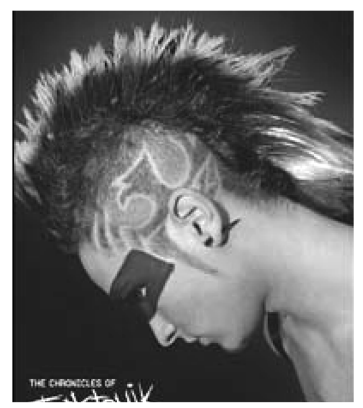

Fig. 14. A mohican haircut.

Retrieved from www.montrealmirror.com colors (Fig. 15), and wear high-top sneakers (Fig. 10), plastic-rimmed sunglasses or shutter shade sunglasses in vivid colors, and neon colored belt or armband.

As the French Tecktonik fashion was transmitted directly to Korea via the online videos, the Korean Tecktonik fashion is basically similar to the French style with skinny pants, high-top shoes and neon colors (Fig. 7), (Fig. 16). The main difference is that a star pattern around the eyes and neon colored tattoos are not used in Korea. And males do not wear mohican haircut nor dark eye make-up. Since unconventional haircuts and dark make-up for men are not easily accepted by Koreans, male entertainers wear moderate Tecktonik fashion not to provoke emotional rejection from the public. Exceptionally, a member of the music group Bigbang tried mohican haircut with dark eye make-up, which drew much attention from people (Fig. 17). But as mentioned above, he borrowed only the fashion, not pursuing Tecktonik music. So, his outstanding fashion style was not an expression

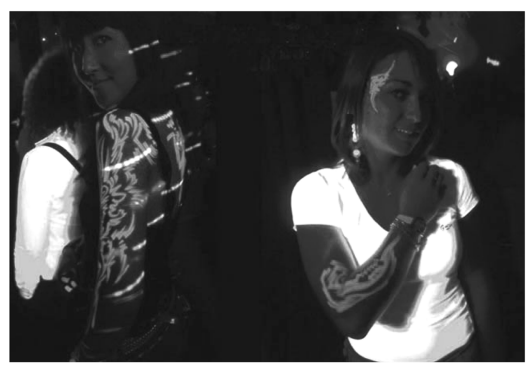

Fig. 15. Neon colored tattoo. Retrieved from http://cafe.naver.com/bluespiritparty

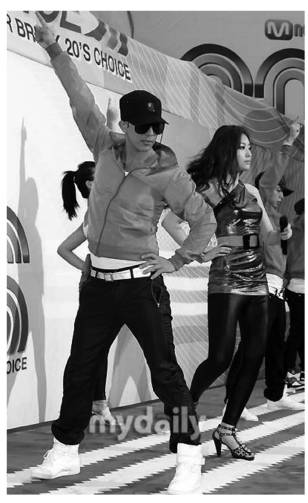

Fig. 16. A Tecktonik singer, DJ Koo. Retrieved from www.mydaily.co.kr 


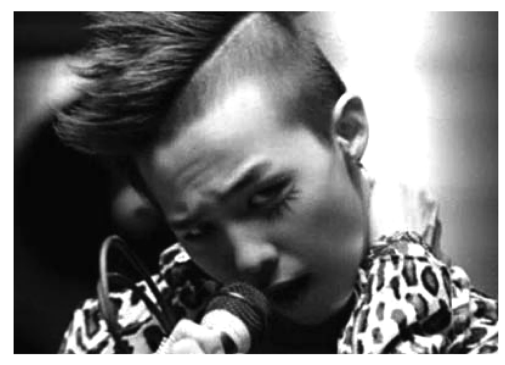

Fig. 17. A member of Bigbang in a mohican haircut. Retrieved from www.newsen.com

of Tecktonik spirit, but just an attempt to a new fashion style. Korean female Tecktoners tend to wear short skirts instead of skinny pants, while their vivid colored leggings or stockings emphasize sexual attraction (Fig. 8), (Fig. 18).

Tecktonik fashion was affected by diverse sources such as contemporary fashion and culture trends, Tecktonik music and dance style, and fashion style of other music genres. Slim fit is related to the skinny fashion trend of the 2000s starting with Dior Homme. Also, men's appearance in dark make-up, bright colored clothes and tight pants reveals metro-sexual

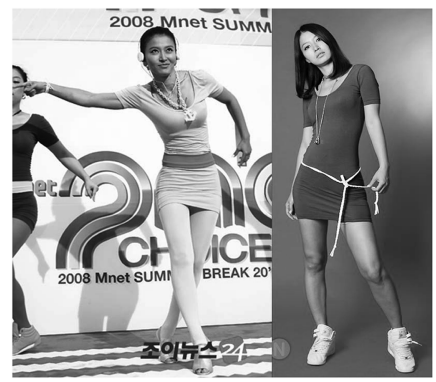

Fig. 18. A Tecktonik singer, Hwang-bo.

Left: Retrieved from http://joynews.inews24.com Right: Retrieved from http://spn.edaily.co.kr/

code. In addition, vivid colors represent strong mechanical feeling of Tecktonik music and dance. The use of vivid colors is effective in making someone stand out in a dance club. Neon colored accessories and slim fit clothes help dance moves look more lively and remarkable. Also, Tecktonik fashion has a revival characteristic. Dark eye shadows and mohican haircut are reminders of punk style, while neon colors, armbands and high-top sneakers are similar features to rave style in the 1980 s.

<Table 1> summarizes Tecktonik fashion style which

Table 1. Tecktonik fashion style

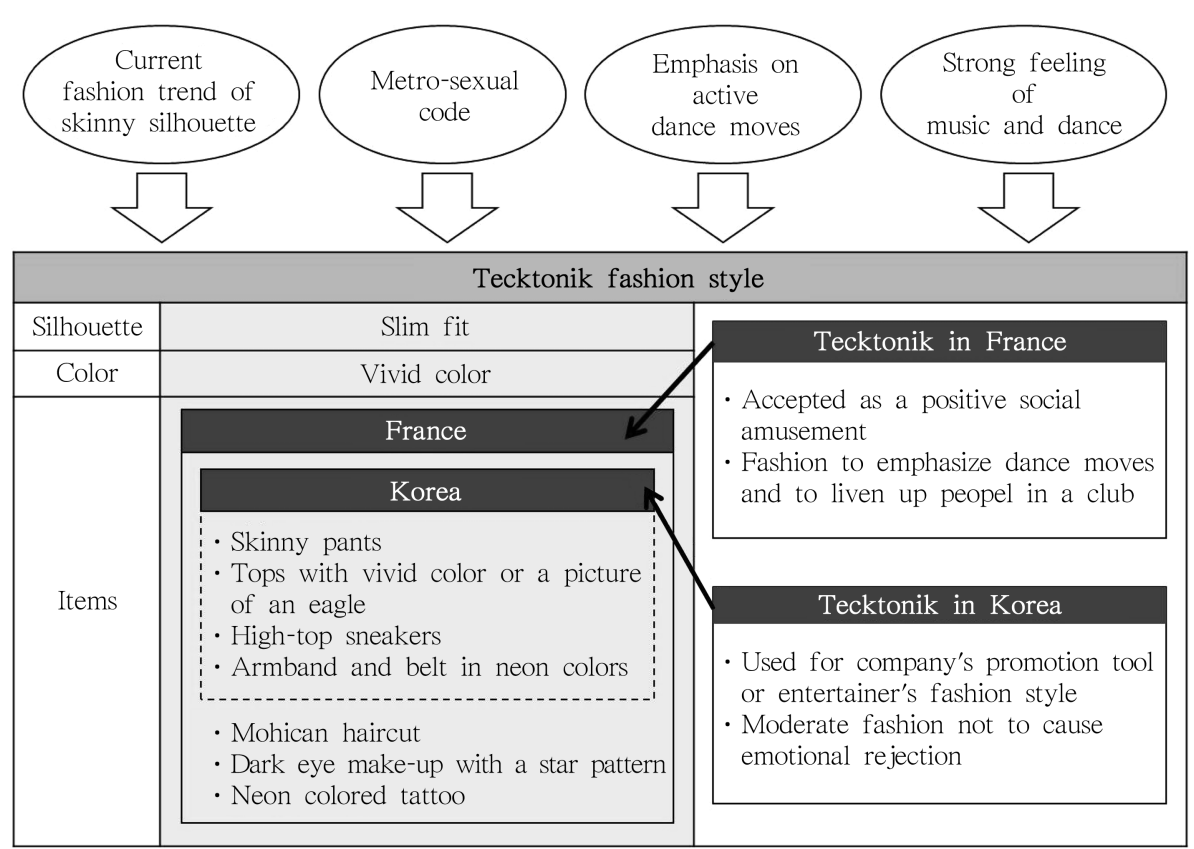


is affected by current fashion trend, culture trend, Tecktonik music and dance, and shows its difference in France and Korea.

\section{Subcultural Features of Tecktonik}

The subcultural features of Tecktonik were identified as follows based on Tecktonik culture and fashion style in France and Korea.

First, Tecktonik is playful rather than resistant. Subculture has been regarded as a way of resistance against the society. For example, Hebdige (1979/1998) insisted that subculture rejects the main culture, and is opposed to predominant values and morals of the society. And according to Richards (1988), young people, who cannot fix the poverty and unemployment of the society, try to escape from the reality through symbolic expressions, and pursue a specific style constituting the subcultural identity. In this context, subcultural fashions such as the black leather jacket and worn-out pants of rockers look, dark make-up, metal chain or safety pin accessories of punk look, big baggy pants of hip-hop style, have been interpreted as anti-social messages of the youth against the old generation (Kim et al., 2006). Among popular dance musics, rave shares many features with Tecktonik but shows a difference in resistance. In the 1980s, rave developed from a warehouse party organized by young businessmen in the United Kingdom and the United States. They made a club in wide open spaces such as a warehouse, airplane hangar, and tent in a farm, which were not typical places for dancing, and people danced to the techno music in the party. In the mid 1990s, people involved in rave began to use the ecstasy, and which brought severe debates in the United Kingdom (Shuker, 1998/1999). In Tecktonik, people also dance to the electronic sound in unconventional wide open spaces. However, unlike rave, Tecktoners enjoy themselves in a sound way without drugs or alcohol. Also, Tecktonik fashion does not express anti-social feeling, instead it goes along with current fashion and culture trends. Its vivid color and outstanding haircut are not for the defiance, but for the joy by adding some elements to make the dance look more lively. Tecktonik has a contradictory nature as a subculture in that it strengthens the existing social system by relieving people from stress through sound activities.

Second, Tecktonik reflects the nature of the IT era by the active use of digital communication media. As prior subcultures originated and were enjoyed mainly in the United Kingdom and the United States, it was difficult for other countries to participate in them. And since they were transmitted in completed forms such as magazines, discs, and music videos, people who enjoyed the culture played limited roles in its development. However, as for Tecktonik, anyone can create his or her own videos and post them on the online sites. Through the Internet, people can share their own opinions and information on Tecktonik with others, so it is easy to add new elements to the craze. As a result, youngsters in various countries are recognized as star Tecktoners among netizens. Furthermore, professional dancers and amateur star Tecktoners offer online dance lesson videos, so that these open sources remove the fear of the beginners and draw more participation. Thanks to the digital media, flow of the information is fast and consumers act as prosumers.

Third, Tecktonik has high commercial value. When a subcultural style is popularized by culture industries, its original resistant or ritual meaning weakens, and the subculture is eventually integrated to the mass culture (Kim, 1994). As mentioned above, Tecktonik has become a registered trademark in France. Even if young people share information and actively participate in creating Tecktonik culture via the Internet, they cannot avoid the commercial strategy of the Tck Company that produces official Tecktonik clothes and music albums, and trains professional dancers. In other words, while the French believe that they simply enjoy the new subculture, they may actually consume commercial products. Moreover, in Korea, Tecktonik is not properly understood, and only its superficial images are consumed. When Tecktonik was searched for in Korean Web sites, it was found that on most of the online sites, where Tecktonik dance or music was supposed to be introduced, only Tecktonik clothes were on sale. Furthermore, the clothes did not show the subcultural identity of Teck- 
tonik, and similar designs could be found in other online shopping sites easily. Namely, Tecktonik was used to attract people for commercial purposes. Since Tecktonik has been used as promotional strategy of companies and broadcasting stations in Korea, it has been degenerated into products, and consumed as the mass culture.

The subcultural features of Tecktonik show a difference in France and Korea. In France, Tecktonik is for participating in a joyful dance, while it acts as a visual entertainment in Korea. Therefore, playfulness is prominent in France and commercial characteristic is strong in Korea. Accordingly, fashion styles show a difference. In France where Tecktonik fashion is for enjoying the dance, there is the active use of vivid colors, dark make-up and mohican haircut in order to emphasize dance moves and liven up people in the club. On the other hand, in Korea where Tecktonik is used for product advertisement or fashion style for famous stars, hairstyle and make-up are restrained because dark make-up or unconventional hairstyle can cause emotional rejection to the consumers and audiences.

\section{Conclusions}

The purpose of this study is to understand the Tecktonik culture and fashion styles, and compare its features in Korea and France. Tecktonik is a dance and music genre that appeared in Paris, in 2000. In France, Tecktonik was readily accepted by the youth, and settled as a positive social amusement. However, in Korea, only its image was used for commercial purposes.

French Tecktoners wear tops in neon colors, tight jumpers or shirts with a picture of an eagle, skinny pants, high-top sneakers, mohican haircut, dark eye make-up, and star pattern drawn around one eye. They also put on plastic-rimmed sunglasses or shutter shade sunglasses in vivid colors, and neon colored tattoos, belts or armbands. Although the Korean Tecktonik fashion is basically similar to the French style, star pattern make-up, dark make-up for men, mohican haircut and neon colored tattoos are rarely used.

Subcultural features of Tecktonik can be identified as follows. First, it is playful rather than resistant. It contradicts the typical anti-social natures of a subculture in that people relieve their stress through Tecktonik and return to the society, eventually strengthening the existing systems. Second, it is a new subculture in the IT era. Information is shared rapidly via the digital communication media, which derives vast participation as prosumers from netizens worldwide. Third, it has high commercial value, which is prominent in Korea. In Korea, Tecktonik is identified as a fad and fashion style of famous people. Also, it is used as marketing tool or promotional strategy of companies and broadcasting stations, thus it has been degraded into a product. Playfulness is prominent in French Tecktonik, while commercial value is outstanding in Korea, which makes differences in Tecktonik fashion of the two countries.

This study is important in that it examines the characteristics and styles of a new subculture, considering that studies on the new subculture after the year 2000 are insufficient. And this study pays attention to how a subculture from a foreign country has been accepted in Korea. The limit of the study is that field study including actual interviews on French and Korean Tecktoners could not be done. As Tecktonik is a new subculture with short history, we should watch what direction it will develop. Also, it is necessary to conduct further studies on various new subcultures besides Tecktonik.

\section{References}

A Tecktonik singer, DJ Koo. (2008, August 23). Mydaily. Retrieved December 5, 2008, from http://www.mydaily. co.kr/news/read.html?newsid=200808231743511131

A Tecktonik singer, Hwang-bo. (2008, August 12). EdailySPN. Retrieved December 5, 2008, from http://spn.edaily.co. $\mathrm{kr} / \mathrm{entertain} /$ newsRead.asp?sub_cd=EA21\&newsid= $01328406586506664 \&$ DirCode $=0010201$

A Tecktonik singer, Hwang-bo. (2008, August 23). Joynews24. Retrieved December 5, 2008, from http://joynews.inews24. com/php/news_view.php?g_serial=352609\&g_menu= 700300

Chung, Y. K., \& Guem, K. (2005). A study on the grunge fashion of the 1990's and 2000's. Journal of the Korean Society of Clothing and Textiles, 29(3,4), 449-461.

Company is engrossed in the Tecktonik dance. (2008, August 
30). Kyungjae Today. Retrieved October 20, 2008, from http://www.eto.co.kr/?Code=20080830092834837\&io= in\&ts $=180036$

Fashion people fall in love with funny looking, toy-like sunglasses. (2008, May 16). Kukminilbo.Kukinews. Retrieved October 20, 2008, from http://www.kukinews.com/news2/ article/view.asp?page $=1 \&$ gCode $=$ eco $\&$ arcid $=0920908609$ $\& \mathrm{cp}=\mathrm{nv}$

France's Tecktonik dance craze. (2008, July 17). Los Angeles Times. Retrieved December 5, 2008, from http:// www.latimes.com/news/nationworld/world/la-fg-teckpg,0,565987.photogallery

G-dragon's mohican haircut (2008, August 19). Newsen. Retrieved December 5, 2008, from http://www.newsen.com/ news_view.php?news_uid=250841

Hebdige, D. (1998). Subcultures: The meaning of style (D. Y. Lee, Trans.). Seoul: Hyun Sil Mun Hwa Yun Gu. (Original work published 1979)

Kim, C. (1994). A study on the popular culture practices of subculture groups: Focused on popular music. Unpublished doctoral dissertation, Seoul National University. Seoul.

Kim, M., \& Lee, S. (2003). A study on the pop music and fashion. Journal of the Korean Society of Costume, 53(2), 101-118.

Kim, S. (2002). A study on the symbolic meaning and influence of punk style. Journal of the Korean Society of Costume, 52(6), 139-164.

Kim, S., Park, K., \& Jeong, H. (2001). A study on hip-hop fashion followed hip-hop culture. Journal of Costume Culture, 9(5), 747-758.

Kim, Y., Kim, S., Kim, J., Kim, H., Song, K., Lee, Y., Lee, H., Jo, A., Joo, M., \& Han, E. (2006). Look, nine view points on fashion. Paju: Kyomoonsa.

Mixed dance with more than five music styles. (2008, February 20). JoongAng Ilbo. Retrieved October 20, 2008, from http://article.joins.com/article/article.asp?Total_ID $=3046624$

Mondotek. (2007). Music video "Alive".

Park, J., \& Ha, J. (2008). A comparative study on Korean and U.S. emo fashion. Journal of the Korean Society of Costume, 58(2), 48-61.

Pretty men lead fashion. (2009, February 2). Herald Media. Retrieved February 2, 2009, from http://www.heraldbiz.com/SITE/data/html_dir/2009/02/02/200902020206. asp

Put on the future clothes on revival dress. What is the secret of popular Tecktonik? (2008, July 28). Mydaily. Retrieved October 20, 2008, from http://www.mydaily.co. $\mathrm{kr} /$ news/read.html?newsid=200807271335411111\&ext $=$ na

Revival style T-shirts and skinny jeans were placed as 1 st and 2nd rankings of Auction hot products in the first half of the year. (2008, June 3). Hankook Ilbo. Retrieved October 20, 2008, from http://news.hankooki.com/lpage/ economy/200806/h2008060303081721540.htm

Richards, L. (1988). The appearance of youthful subculture. CTRJ, 6(3), 56-64.

Right on q. (2008, April 3). The Montreal Mirror. Retrieved December 5, 2008, from http://www.montrealmirror.com/ 2008/040308/clubland3.html

Shuker, R. (1999). Key concepts in popular music (J. Y. Lee \& H. Y. Jang, Trans.). Seoul: Han Na Re. (Original work published 1998)

Sohn, H., \& Park, K. (2005). Study on the characteristics of modern punk fashion. Journal of the Korean Society of Clothing and Textiles, 29(11), 1444-1453.

Techno Parade 2007 @ Paris. (2007). Flickr. Retrieved December 5, 2008, from http://www.flickr.com/photos/ tolitoli/sets/72157602033847294

Tecktonik. (2008, September 21). Wikipedia. Retrieved October 20, 2008, from http://ko.wikipedia.org/wiki/\%ED $\% 85 \% 8 \mathrm{C} \% \mathrm{ED} \% 81 \% \mathrm{AC} \% \mathrm{ED} \% 86 \% \mathrm{~A} 0 \% \mathrm{~EB} \% 8 \mathrm{~B} \% 89$.

Tecktonik, a dance of Mabbaki originated from Paris. (2008, February 20). JoongAng Ilbo. Retrieved October 20, 2008, from http://article.joins.com/article/article.asp?total _id $=3047023 \& \mathrm{ctg}=1200$

Tecktonik culture. (2008, May 17). Blue Spirit Party Cafe. Retrieved December 5, 2008, from http://cafe.naver.com/ bluespiritparty/66

Tecktonik dance and life style. (2008, February 4). ZakShow.com. Retrieved December 5, 2008, from http:// www.zakshow.com/2008/02/04/tecktonik-dance-andlife-style

Tecktonik dance craze in France today. (2008, July 18). Chosun Ilbo. Retrieved October 20, 2008, from http:// news.chosun.com/site/data/html_dir/2008/07/18/20080 71801470.html

Tecktonik dance craze takes Paris by storm. (2007, September 19). Agence France Presse. Retrieved October 20, 2008, from http://afp.google.com/article/ALeqM5iMOo 7HY35Wk2ij6aZ8rFC548eHXQ

Tecktonik fad shaking the world. (2008, August 29). Maeil Kyungjae. Retrieved October 20, 2008, from http://news. mk.co.kr/outside/view.php?year $=2008 \&$ no $=533856$

Tecktonik fashion. (2008, June 21). Never Blog. Retrieved October 20, 2008, from http://blog.naver.com/customnara/40052358625

Tecktonik: it's techno with a Parisian twist - a lot of really crazy twists. (2008, January 29). The Christian Science Monitor. Retrieved December 5, 2008, from http:// www.csmonitor.com/2008/0129/p01s10-woeu.html

The turf war over a dance craze. (2008, April 11). The Wall Street Journal. Retrieved October 20, 2008, from http:// online.wsj.com/article/SB120785786466805751.html? mod=hpp_us_inside_today 
Topic in the capital, catch up with the Tecktonik fad. (2008, September 26). Sportschosun. Retrieved October 20, from http://sports.chosun.com/news/ntype2.htm?ut=1\&name $=/$ news $/$ life $/ 200809 / 20080927 / 89723005 . h t m$

Yelle. (2007). Music video "A cause des garcons".
10 hot products in the first half of the year announced by Auction. (2008, June 2). Kyungjae Today. Retrieved October 20, 2008, from http://www.eto.co.kr/?Code= $20080602181659763 \&$ ts $=183745$

\section{요 약}

본 연구의 목적은 테크토닉 문화 및 패션의 특징을 파악하고, 한국과 프랑스에서 테크토닉 문화와 패션 이 갖는 특수성을 밝히는 것이다. 특히 그 동안 주로 연구되었던 영 - 미권이 아닌 한국에서 하위문화가 어 떻게 확산, 향유되는지에 주목하였다. 테크토닉은 2000년 프랑스 파리의 한 클럽에서 등장한 댄스 장르이 자 음악 장르로, 인터넷을 통해 전 세계적으로 전파되었다. 테크토닉 패션은 슬림한 라인, 강렬한 색상, 하이탑 스니커즈를 특징으로 하는데, 이러한 패션 스타일은 동시대 패션의 흐름과 맞물리면서 테크토닉 댄스와 음악의 성격을 표현한다. 프랑스와 비교하여, 한국 테크토닉 패션 스타일은 남성의 경우 진한 메 이크업과 모히칸 헤어를 잘 시도하지 않으며, 여성은 짧은 치마로 섹시함을 강조하는 경향이 있다. 테크 토닉의 발생지인 프랑스에서는 테크토닉이 긍정적인 사회적 놀이문화로서 자리매김했으나, 한국의 테크 토닉은 그 이미지만이 차용되어서 연예인의 패션 스타일이나 광고 수단으로 상품화되었다. 하위문화로서 테크토닉은 놀이성, 상품성, 디지털 통신매체의 적극적인 이용이라는 특수한 성격을 가진다. 테크토닉을 즐거운 댄스에 참여하는 것으로 여기는 프랑스에서는 놀이성이 두드러지고, 테크토닉을 시각적인 흥미요 소로 여기는 한국에서는 상품성이 두드러진다. 이러한 성격의 차이가 두 나라의 테크토닉 패션에 차이를 가져왔다. 